\title{
PENGARUH LIMBAH CAIR PERAWATAN CANDI BOROBUDUR TERHADAP FISIOLOGIS IKAN MAS (Cyprinus caprio)
}

\author{
Danni Gathot Harbowo \\ Program Studi Jurusan Biologi \\ Sekolah Ilmu dan Teknologi Hayati, Institut Teknologi Bandung
}

Penggunaan biocide untuk perawatan batuan Candi Borobudur menghasilkan residu yang mampu merusak kualitas air tanah di sekitar kawasan Candi Borobudur. Penelitian ini bertujuan untuk mengetahui perubahan fisiologi ikan mas (Cyprinus carpio) yang dipaparkan dengan limbah cair perawatan Candi Borobudur. Penelitian ini dilaksanakan pada tanggal 12 Juli 2011 hingga 20 Juli 2011 di Laboratorium Balai Konservasi Peninggalan Borobudur Magelang, Jawa Tengah. Ikan mas berumur 3 minggu dengan berat 2-4 gram diujikan pada media yang mengandung limbah dari perawatan Candi Borobudur. Limbah cair tersebut diduga mengandung biocide yang terlarut akibat aktifitas perawatan. Perubahan fisiologis ikan mas dalam penelitian ini diamati melalui perrhitungan frekuensi gerakan mulut dan sirip ikan (pectoral fin), serta morfologi struktur jaringan insang dan hati ikan mas. Hasil penelitian ini menunjukkan bahwa terhitung 20 Juni 2011, secara umum limbah cair yang dihasilkan dari kegiatan perawatan Candi Borobudur tidak menyebabkan fisiologi ikan mas (Cyprinus carpio) terganggu. Semua pembanding antar perlakuan tidak menunjukan perbedaan nyata, kecuali pada sayatan insang ikan. Ikan yang diberi perlakuan air limbah akan muncul partikulat hitam yang ada disekitar lamella insang ikan. Partikulat hitam tersebut kemungkinan merupakan sisa-sisa abu letusan Gunung Merapi.

\section{PENDAHULUAN}

Penggunaan biocide dalam perawatan batuan Candi Borobudur seringkali meninggalkan residu yang masih memiliki sifat racun (Santoso, 2004). Beberapa biocide yang digunakan menyebabkan gangguan kesehatan manusia (Daffus, 1980), seperti biocide jenis Hyamin ${ }^{\circledR}$. Jenis biocide ini digunakan untuk menghindari pertumbuhan mikroorganisme pada batuan Candi Borobudur yang mampu menyebabkan pelapukan (Swastikawati, 2007).

Penggunaan biocide pada batuan candi dapat mencemari lingkungan ketika terlarut bersama air. Pelarutan biocide tersebut dapat terjadi ketika proses penyemprotan uap bertekanan (untuk perawatan candi) ataupun akibat pelarutan air hujan. Air yang mengandung biocide (limbah) tersebut ditampung dalam sumur resapan yang berada di dekat bak kontrol (Santoso, 2004). Limbah perawatan candi tersebut beresiko dapat mencemari lingkungan. Oleh karena itu keberadaan limbah tersebut perlu ditangani dengan tepat dan perlu dilakukan analisis untuk menentukan tingkat pencemaran dari limbah biocide perawatan candi tersebut.

Diketahui pula bahwa ikan mas (Cyprinus caprio) merupakan salah satu bioindikator yang memiliki sensitifitas yang tinggi pada pencemaran perairan (Chahaya, 2003). Sensitifitas tersebut dapat terlihat pada perubahan fisiologi ikan mas tersebut ketika terjadi perubahan pada habitatnya. Perubahan fisiologis tersebut dapat terlihat melalui perubahan perilaku, struktur jaringan, ataupun aktifitas fisiologis lainnya (Kikkawa, 1974). Selain itu, ikan mas juga merupakan salah satu komuditas pangan yang banyak dikonsumsi masyarakat (Rusdi, 2008). Mengkonsumsi ikan mas yang terkontaminasi dengan bahan pencemar tentu akan memberikan dampak buruk bagi tubuh (White, 2007). Oleh karena itu, ikan mas dinilai cocok digunakan sebagai bioindikator untuk melihat dampak penggunaan biocide terhadap pencemaran lingkungan perairan.

Sebelum melakukan penanganan limbah dari perawatan candi, diperlukan suatu analisis untuk menilai besarnya dampak dari pencemaran. Dampak pencemaran tersebut dapat dianalisis dengan menggunakan agen biotik sebagai bioindikator (Molles, 2008). Dari beberapa hal tersebut maka diadakan suatu penelitian untuk menganalisis dampak lingkungan dari hasil buangan limbah perawatan Candi Borobudur (biocide) melalui perubahan fisiologis ikan mas. Dalam penelitian ini perubahan fisiologis dianalisis melalui perubahan frekuensi perilaku, dan perubahan struktur morfologi jaringan organ ikan mas.

\section{METODE PENELITIAN}

Penelitian dilakukan selama 9 hari, dimulai pada tanggal 12 Juni 2011 hingga tanggal 20 Juni 2011. Penelitian dilaksanakan Balai Konservasi Peninggalan Borobudur, Magelang Jawa Tengah. Hewan yang digunakan dalam penelitian ini adalah ikan mas (Cyprinus carpio Linn) berumur 3 bulan, dengan ukuran berkisar 7 $10 \mathrm{~cm}$, memiliki berat badan berkisar 2-4 gram, warna yang sama, memiliki kondisi yang sehat, dan berasal dari pembibitan kolam yang sama. 
Proses Aklimatisasi. Sebelum diberi perlakuan, ikan mas diaklimatisasi selama 3 hari dalam keadaan normal $\left( \pm 25^{\circ} \mathrm{C}, 1 \mathrm{~atm}\right)$. Selama 3 hari tersebut 32 ekor ikan mas dibagi secara acak menjadi 8 kelompok dengan jumlah yang sama. Setiap kelompok ditempatkan di aquarium yang telah terisi dengan medium sebanyak 6 liter. Selama proses tersebut ikan dibiarkan dengan keadaan pencahayaan mengikuti siklus harian dan tanpa sirkulasi air. Dalam penelitian ini terdapat dua perlakuan, yaitu perlakuan pendedahan air limbah dan perlakuan kontrol. Pengulangan sistem pada setiap perlakuan sebanyak 4 kali dengan jumlah individu atau bejana sebanyak 4 ekor

Proses Perlakuan. Setelah diaklimitasi, ikan dipindahkan ke bejana perlakuan. Terdapat 4 bejana perlakuan yang berisi air limbah dan 4 bejana yang telah terisi air kran. Air limbah yang digunakan adalah gabungan air bak kontrol dari 8 titik yang telah dihomogenisasi secara merata. Proses perlakuan dilakukan selama 4 hari.

Proses Pengambilan Data. Selama 4 hari proses perlakuan, data diambil 2 kali sehari (pukul 9.00 dan 15.00). Data yang diambil adalah frekuensi gerakan mulut ikan dan gerakan sirip dada ikan. Frekuensi dihitung dengan satuan gerakan permenit. Data yang diambil merupakan sampel dari populasi. Ikan yang digunakan sebagai sampel dipilih secara acak disetiap bejana dengan menggunakan metode random number. Diakhir perlakuan (hari terakhir) seluruh ikan dibedah lalu diamati struktur, morfologi jaringan insang dan hati ikan. Perbedaan yang dibandingkan adalah keadaan situs ficerum serta struktur jaringan dalam preparat. Nilai $\mathrm{pH}$ air, temperatur air, dan selisih berat badan ikan digunakan sebagai data sekunder. Data $\mathrm{pH}$ dan temperatur air diambil sejak dilakukan proses aklimatisasi hingga akhir perlakuan sebanyak 2 kali dalam sehari, sedangkan selisih berat badan diambil diawal dan diakhir perlakuan.

Proses Pengolahan Data. Data yang diolah secara kuantitatif dan pengamatan kualitatif. Data yang didapat di akhir penelitian adalah frekuensi gerakan mulut dan sirip ikan, gambar struktur dan morfologi jaringan hati dan insang ikan mas (situs ficerum dan preparat), selisih berat badan ikan, $\mathrm{pH}$ dan temperatur air bejana perlakuan. Data yang telah didapat dibandingkan dan dianalisis secara statistik dengan menggunakan tabel sidik ragam, grafik, dan analisis varians (ANOVA). Gambar struktur dan morfologi jaringan hati dan insang ikan mas (situs ficerum dan preparat) dibandingkan dalam bentuk foto.

\section{HASIL}

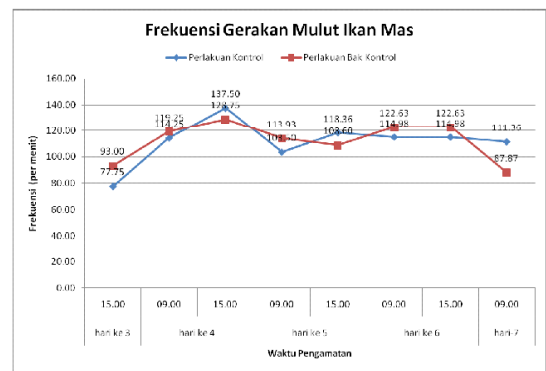

Gambar 3.1 Frekuensi (per menit) gerakan mulut Cyprinus caprio selama perlakuan

Grafik diatas (gambar 3.1) menunjukan bahwa perubahan frekuensi gerakan mulut dari hari pertama perlakuan hingga akhir perlakuan memiliki arah kecenderungan yang sama dan berdasarkan analisis statistik menunjukan kedua perlakuan tersebut tidak berbeda nyata.

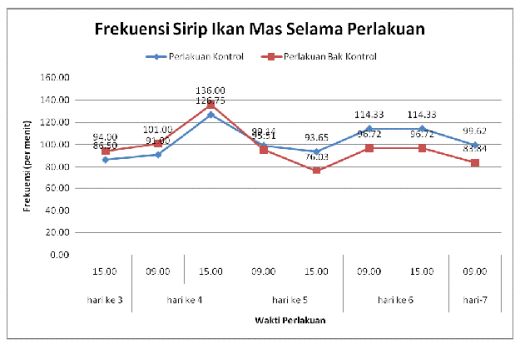

Gambar 3.2 Frekuensi (per menit) gerakan sirip Cyprinus caprio selama perlakuan.

Sama halnya dengan frekuensi gerakan mulut, gambar 3.2 menunjukan bahwa gerakan sirip tiap perlakuan memiliki kecenderungan yang sama dan berdasarkan analisis statistik menunjukan kedua perlakuan tersebut tidak berbeda nyata. Berdasarkan gambar situs ficerum (gambar 3.3), terlihat struktur morfologi insang dan hati ikan yang masih segar. Gambar tersebut menunjukkan tidak ada perbedaan warna insang dan warna hati ikan yang sangat mencolok antara perlakuan. Keseluruhan situs ficerum ikan tersebut menunjukan warna merah tua pada insang dan merah hitam pekat pada hati ikan.

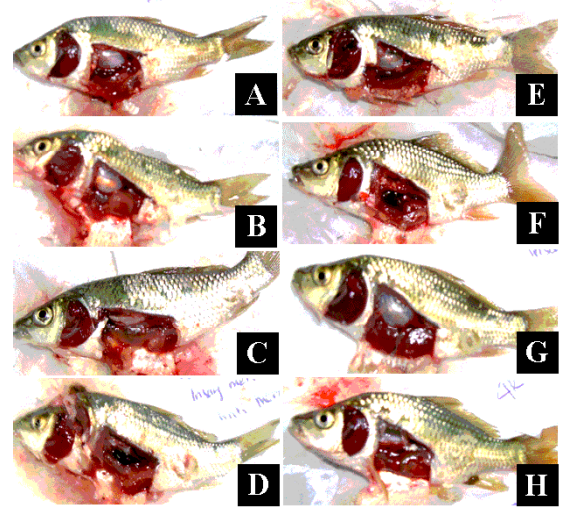

Gambar 3.3 Situs ficerum ikan mas yang setelah perlakuan 


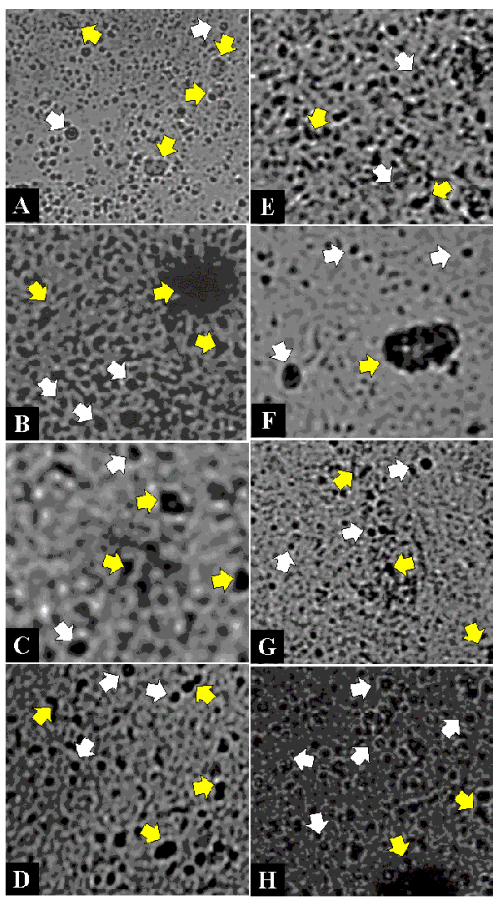

Gambar 3.4 Struktur jaringan hati ikan mas yang setelah perlakuan perbesaran 400
Terlihat jelas di gambar 3.4, hampir diseluruh jaringan hati terdapat sel bepatocyte yang menyusun jaringan hati ikan. Sel hepatosit normal akan memiliki inti berbentuk bundar dengan titik kecil di bagian tengahnya. Gambar tersebut juga menunjukan terdapat beberapa bagian jaringan mengalami focal necrosis. Focal necrosis $\mathrm{m}$ e r u p a k a fenomena kematian be be rapa s e l hepatosit akibat pengaruh dan di

bagian tertentu pada jaringan. Namun dari gambar preparat ini tidak bisa digunakan untuk mengukur ukuran sel, kepadatan sel, serta frekuensi focal necrosis pada jaringan hati ikan. Oleh sebab itu sulit untuk mengkuantifikasi perubahan struktur jaringan hati akibat perlakuan. Hal itu disebabkan karena gambar preparat kurang memadai untuk proses perhitungan, gambar memiliki ketajaman yang rendah serta memiliki kecerahan gambar yang terlalu gelap sehingga sulit ditentukan tentang perlakuan limbah

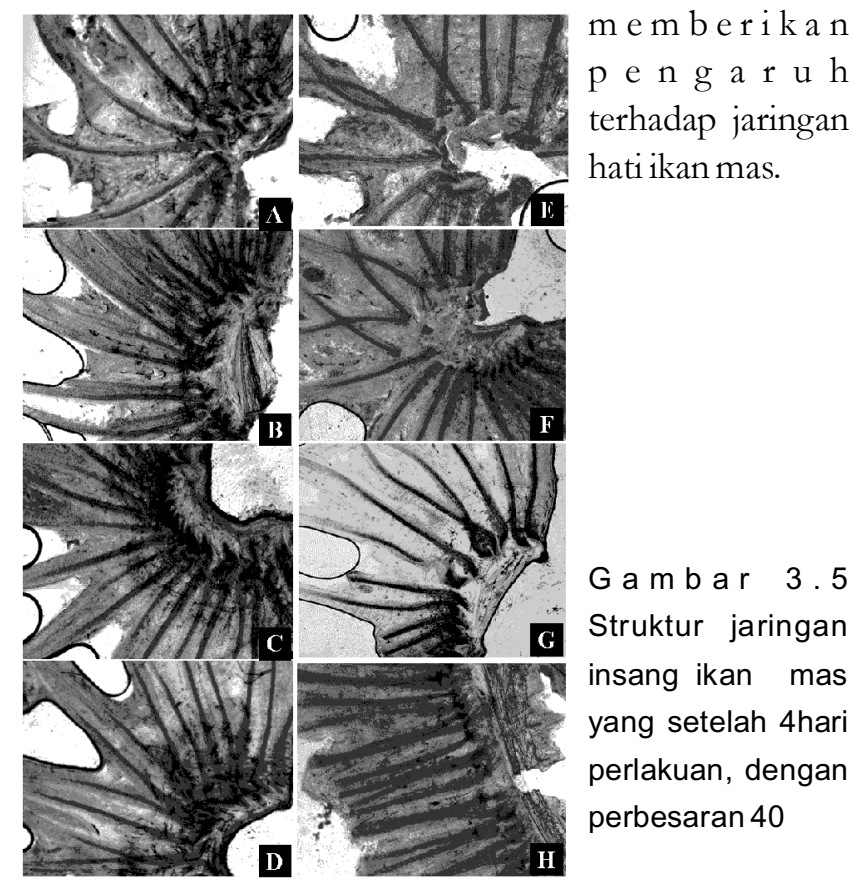

Keterangan label:
A: BakKontrol-1, B:BakKontrol-2,
C:BakKontrol-3, D:BakKontrol-4,
E:Kontrol-1, F: Kontrol-2,
G: Kontrol-3, H: Kontrol-4.

Terlihat jelas di gambar 3.4, hampir di jaringan hati ikan perlakuan terdapat sel hepatocyte. Sel hepatosit normal akan memiliki inti berbentuk bundar dengan titik kecil di bagian tengahnya. Berdasrkan gambar tersebut terlihat pula beberapa bagian jaringan mengalami focal necrosis. Focal necrosis tersebut merupakan fenomena akibat kematian beberapa sel hepatosit akibat pengaruh dan di bagian tertentu pada jaringan. Namun dari gambar preparat ini, tidak bisa digunakan untuk mengukur ukuran sel, kepadatan sel, serta frekuensi focal necrosis pada jaringan hati ikan.

Sedangkan pada gambar 3.5 bahwa insang yang diberi perlakuan kontrol terdapat beberapa agregat hitam yang terkumpul di dekat kartilago insang. Partikulat hitam tersebut menempel dan melekat di lamella insang. Partikulat hitam tersebut juga terdapat pada insang yang diberi perlakuan kontrol walaupun jumlahnya tidak sebanyak perlakuan limbah. Belum diketahui secara pasti komposisi dari partikulat hitam tersebut, dimungkinkan partikulat tersebut merupakan sisa abu vulkanik dari letusan gunung Merapi yang terjadi pada Oktober 2010 dan November 2010.

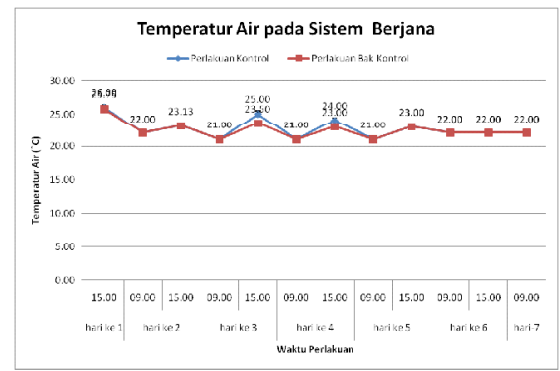

Gambar 3.6 Temperatur air $\left({ }^{\circ} \mathrm{C}\right)$ sistem bejana perlakuan.

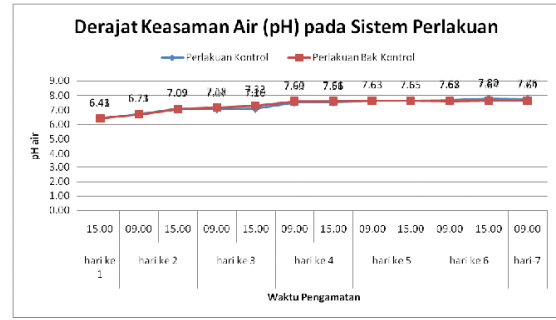

Gambar 3.7 Derajat Keasaman $(\mathrm{pH})$ sistem bejana perlakuan.

Kemudian berdasarkan pengukuran temperatur dan $\mathrm{pH}$ air dalam bejana perlakuan menunjukan kecenderungan grafik yang sama. Setelah dianalisis secara 
statistik, didapat bahwa keadaan bejana antara perlakuan kontrol dan limbah tidak menunjukan perbedaan nyata.

\begin{tabular}{|c|c|c|c|c|c|}
\hline \multirow{2}{*}{ Perlakuan } & \multicolumn{4}{|c|}{ Ulangan } & \multirow{2}{*}{ Rataan } \\
\cline { 2 - 5 } & 1 & 2 & 3 & 4 & \\
\hline$\Delta \mathrm{W}$ Kontrol* & $-7,33$ & $-4,62$ & 0,01 & $-5,33$ & $-4,32$ \\
\hline$\Delta \mathrm{W}$ Bakon** &,- 33 & 5,15 & 4,86 & $-1,22$ & 2,11 \\
\hline
\end{tabular}

Tabel 3.1 Rataan selisih berat ikan (gram) selama 4 hari (48 jam)

Keterangan:

$\triangle W$ : selisih berat ikan (gram);

* Perlakuan kontrol;

**Perlakuan limbah

Namun dari data rataan selisih berat badan ikan selama perlakuan menunjukan perbedaan nyata secara statistik. Perlakuan kontrol memiliki selisih relatif lebih besar dibandingkan perlakuan limbah.

\section{PEMBAHASAN}

Rangkaian penelitiaan ini dilakukan untuk membantu mengkuantifikasi, menganalisis, dan merancang rencana penanganan limbah lebih akurat dan efektif. Salah satu metode yang digunakan untuk menganalisis dampak limbah tersebut digunakan bioindikator. Bioindikator merupakan agen biologis (organisme) yang dapat digunakan untuk mengindikasi suatu perubahan lingkungan yang diindikasi dari perubahan aktifitas fisiologi organisme tersebut (Chahaya, 2003).

Ikan mas (Cyprinus caprio) merupakan ikan yang dapat digunakan sebagai bioindikator pencermaran perairan. Ikan mas memiliki respon terhadap perubahan lingkungan yang lebih sensitif dibandingkan ikan lainnya. Terdapat beberapa kriteria yang mendukung bahwa ikan mas dapat digunakan sebagai bioindikator (Chahaya, 2003), yaitu:

$\square$ Organisme sensitif terhadap material beracun dan perubahan lingkungan

$\square$ Penyebarannya luas dan mudah didapat dalam jumlah yang banyak

$\square$ Mempunyai arti ekonomi, rekreasi, dan kepentingan ekologi

$\square$ Mudah dipelihara dalam laboratorium

$\square$ Mempunyai kondisi yang baik, bebas dari penyakit, dan parasit

$\square$ Sesuai untuk kepentingan uji hayati.

Perubahan pada lingkungan perairan diamati melalui perubahan fisiologis ikan mas berdasarkan perubahan perilaku dan morfologi organ. Untuk melihat perubahan tersebut dalam penelitian ini, perilaku ikan mas dan perubahan struktur jaringan organ diamati sebagai indikator utama dalam perubahan lingkungan perairan. Perilaku ikan mas yang diamati adalah perilaku gerakan sirip dada (pectoral fin) dan gerakan mulut ikan. Sedangkan perubahan struktur jaringan diamati pada perubahan struktur jaringan insang dan hati.

Gerakan mulut ikan mas merupakan respon dari fisiologis ikan mas dalam proses respirasi dan proses pencernaan. Dalam waktu yang konstan, gerakan mulut ikan akan berbanding lurus dengan gerakan operculum ikan. Dalam proses respirasi ikan, ikan akan memasukan air melalui mulut untuk diteruskan ke rongga insang yang ada di bagian dalam operculum. Air akan berkontak langsung dengan insang ikan untuk proses difusi gas oksigen dari molekul air menuju pembuluh darah ikan. Oksigen yang masuk ke dalam pembuluh darah tersebut akan disalurkan untuk proses respirasi intraseluler pada jalur metabolisme aerob (Kramer, 1987). Oleh sebab itu gerakan mulut ikan dapat digunakan untuk melihat aktifitas respirasi ikan. Ikan mas akan menggerakan mulut lebih cepat (frekuensi relatif tinggi) ketika kebutuhan oksigen di dalam tubuh tidak tercukupi ataupun ketika kandungan oksigen pada perairan tersebut relatif lebih rendah. Keadaan tersebut akan memicu ikan untuk mengambil air sebanyak-banyaknya dengan menggerakan mulut lebih cepat untuk mencukupi kebutuhan oksigen. Jika kebutuhan oksigen tidak dapat tercukupi maka ikan mengalami penurunan frekuensi gerakan mulut yang signifikan dan kemudian pingsan atau mati (Kramer, 1987).

Frekuensi sirip dada (pectoral fin) juga diamati dalam penelitian ini. Sirip dada merupakan salah satu organ keseimbangan yang terdapat di luar tubuh ikan. Sirip dada ikan mas terletak di bagian ventral, di bawah operculum, baik sisi kanan ataupun kiri dari sumbu tubuh (Souisa, 2010). Sirip dada ikan mas disusun oleh kartilago yang tersusun sejajar dan dilapisi selaput tipis. Dalam keadaan statis (diam), gerakan pectoral fin berguna untuk menjaga keseimbangan lateral ikan (Drucker, 1996). Sirip dada tersebut akan digerakan secara konstan dan beriringan antara sirip dada kanan dan kiri. Perubahan kondisi perairan dapat mengganggu sistem koordinasi saraf pusat ikan, khususnya pada sistem keseimbangan tubuh. Gangguan seperti pendedahan racun ataupun perubahan kondisi fisik perairan mampu mengganggu respon fisiologis yang kemudian menganggu sistem keseimbangan tubuh (White, 2007). Gangguan pada sistem keseimbangan tubuh akan terlihat pada gerakan sirip dada ikan mas. Rendahnya frekuensi gerakan sirip ikan mas akan menganggu keseimbangan tubuh yang 
kemudian posisi ikan menjadi tidak lurus atau miring (Drucker, 1996). Posisi yang tidak normal ini menunjukan bahwa terdapat kerusakan atau gangguan pada sistem saraf, khususnya sistem keseimbangan. Oleh karena itu perubahan kondisi perairan dapat diamati dari frekuensi gerakan sirip dada ikan mas.

Berdasarkan data yang didapat dari hasil pengamatan, menunjukan bahwa gerakan mulut dan sirip antara ikan yang diberi perlakuan kontrol dan limbah tidak memberikan perbedaan nyata. Dalam data yang telah dianalisa terlihat bahwa rataan frekuensi gerakan mulut ikan mas antara perlakuan kontrol dan perlakuan limbah memiliki nilai yang berdekatan, yaitu 112 gerakan per menit untuk perlakuan kontrol dan 112 gerakan per per menit untuk perlakuan limbah. Kedua nilai ini hampir sama dengan nilai yang didapat oleh Souisa (2009) 111 gerakan per menit. Untuk frekuensi gerakan sirip, nilai rataan frekuensi gerakan sirip ikan tersebut, yaitu 103 gerakan per menit untuk perlakuan kontrol dan 97 gerakan per menit untuk perlakuan limbah. Dengan demikian dapat disimpulkan bahwa perlakuan limbah tidak memberikan pengaruh terhadap fisiologis ikan mas yang terkait dengan gerakan mulut dan sirip ikan mas.

Berdasarkan hasil pengamatan situs ficerum, bagian hati dan insang pada keseluruhan perlakuan memiliki warna yang sama dan tidak mengalami perbedaan struktur pada organ. Warna yang teramati pada saat pembedahan adalah merah tua pada bagian insang dan merah pekat pada bagian hati insang. Penampakan warna ini, menunjukan bahwa organ-organ tersebut masih berfungsi dan memiliki sel jaringan yang masih hidup. Warna merah yang terlihat pada sel adalah warna senyawa kompleks dari hemoglobin darah yang memiliki ikatan dengan unsur besi. Unsur besi yang ada dalam hemoglobin tersebut akan membantu dalam pengikatan oksigen dalam proses respirasi intraseluler.

Kemudian pada pengamatan struktur jaringan hati ikan (Gambar 3.3) terlihat adanya aktifitas focal necrosis pada jaringan hati ikan pada seluruh perlakuan. Focal necrosis adalah kondisi dimana proses kematian sel yang diakibatkan oleh faktor eksternal sel yang terjadi pada luas area yang tidak dapat terlihat oleh mata (mikroskopik). Focal necrosis ini dapat disebabkan oleh racun, infeksi, ataupun trauma sel (Raskovic, 2010). Kematian sel seperti ini akan menyebabkan fungsi hati menjadi menurun, proses detoksifikasi racun yang ada dalam tubuh akan semakin terhambat yang kemudian dapat menyebabkan ikan menjadi keracunan (Ayotunde, 2011). Pada penelitian ini focal necrosis hampir terjadi diseluruh perlakuan. Hal ini mungkin disebabkan oleh peningkatan ammonium pada bejana perlakuan. Senyawa ammonium merupakan senyawa racun yang dieksresikan oleh ikan melalui feses ataupun urin. Dalam perkembangan struktur organ, pendedahan ammonium pada ikan akan menyebabkan perubahan jaringan pada insang, hati, dan ginjal. Efek racun yang ditimbulkan seperti hyperexcitability, meningkatkan aktivitas pernafasan, dan meningkatnya frekuensi detak jantung. Pada konsentrasi tinggi, ikan dapat mengalami kejang, koma, hingga kematian (Lewis, 1986).

Namun data pengamatan struktur jaringan hati tersebut (Gambar 3.4) tidak bisa digunakan untuk mengukur ukuran sel, kepadatan sel, serta frekuensi focal necrosis pada jaringan hati ikan sebagai analisis kerusakan. Oleh sebab itu sulit untuk mengkuantifikasi perubahan struktur jaringan hati akibat perlakuan. Hal itu disebabkan karena gambar preparat yang didapat kurang memadai untuk proses perhitungan, gambar memiliki ketajaman yang rendah serta memiliki kecerahan gambar yang terlalu gelap.

Kemudian pada gambar sayatan insang (Gambar 3.5) terlihat bahwa insang yang diberi perlakuan kontrol terdapat beberapa agregat hitam yang terkumpul didekat kartilago insang. Partikulat hitam tersebut menempel dan melekat pada lamella insang dalam jumlah yang relatif lebih banyak dibandingkan perlakuan kontrol. Partikulat hitam tersebut juga terdapat pada insang yang diberi perlakuan kontrol walaupun jumlahnya tidak sebanyak perlakuan limbah. Belum diketahui secara pasti komponen dari partikulat hitam tersebut, dimungkinkan partikulat tersebut merupakan sisa abu vulkanik dari letusan gunung Merapi yang terjadi pada Oktober 2010 dan November 2010.

Nampaknya partikulat hitam tersebut menutupi sebagian lamella insang yang merupakan jaringan tempat terjadinya proses difusi oksigen. Penampakan jaringan insang pada perlakuan kontrol memiliki kondisi yang lebih bersih dibandingkan jaringan insang yang diberi perlakuan limbah. Berdasrkan hasil pengamatan yang dilakukan, partikulat hitam tersebut sulit untuk dideterminasi komponennya. Namun dari penampakan air ketika perlakuan, terlihat air bak kontrol (limbah) lebih keruh dibandingkan dengan air kran (kontrol). Diduga dalam air bak kontrol memiliki kandungan TDS (Total Dissolved Solid) yang lebih tinggi dibandingkan air kran sebagai kontrol. Hal ini didukung oleh hasil analisis kimia air bak kontrol yang dilakukan oleh Laboratorium Kimia Balai Konservasi Peninggalan Borobudur pada bulan April 2010 menunjukan bahwa kandungan suspensi pada air bak kontrol relatif lebih tinggi dibandingkan air 
kontrol (dalam hal ini air hujan). Perbedaan kandungan suspense solids ini diduga disebabkan oleh erosi atau pengikisan tanah pengisi Candi Borobudur (Santoso, 2004).

Selain itu dari hasil pengamatan ketika mengamati bak kontrol di lokasi (lapangan) terlihat dalam air yang ada dalam bak tersebut banyak mengandung suspensi abu vulkanik sisa dari letusan Gunung Merapi yang terjadi pada bulan Oktober dan November 2010. Abu vulkanik tersebut tidak dapat larut bersama air dan akan membentuk suspensi pada yang mudah terbawa bersama air.

\begin{tabular}{|c|c|c|}
\hline JENIS SAMPEL AIR & TDS (ppm) & Tabel 4.1 To \\
\hline Air Hujan & 46.11 & (TDS) air b \\
\hline Air bak kontrol Utara 2 & 175.8 & Borobudur pa \\
\hline Air bak kontrol barat laut & 139.7 & $(\mathrm{~S} u \mathrm{mb} e$ \\
\hline Air bak kontrol barat daya & 223.6 & Kimia Ba \\
\hline Air bak kontrol selatan & 187 & Peningga \\
\hline Air bak kontrol Utara 1 & 366.1 & \\
\hline Air bak kontrol Timur & 420.3 & \\
\hline
\end{tabular}

Penutupan insang oleh partikulat hitam pada bagian lamella ikan, mampu menyebabkan gangguan pada sistem respirasi ikan. Proses difusi oksigen menuju pembuluh darah akan terganggu dan laju difusi oksigen akan menurun. Penurunan laju difusi oksigen tersebut akan menyebabkan kurangnya jumlah oksigen pada sel sehingga proses metabolisme aerob pada sel ikan akan menurun. Jika kebutuhan oksigen ikan tidak dapat terpenuhi, metabolisme ikan akan berjalan secara anaerob pada jangka waktu tertentu. Metabolisme anaerob akan menghasilkan senyawa asam yang dapat merusak tubuh. Jika metabolisme anaerob ini terus dilakukan, ikan akan mengalami keracunan asam otot dan kemudian mengalami kematian. Namun selain TDS, temperatur dan $\mathrm{pH}$ air juga mempengaruhi fisiologis ikan mas untuk melakukan proses metabolisme.

Untuk mengkonfirmasi dan mendukung hal tersebut, digunakan data temperatur dan $\mathrm{pH}$ air pada bejana perlakuan selama pengamatan. Dari data yang dihasilkan menunjukan bahwa temperatur dan $\mathrm{pH}$ selama perlakuan antara perlakuan kontrol dan perlakuan limbah tidak berbeda nyata. Dengan demikian dapat disimpulkan, keadaan fisika dan kimia pada bejana tersebut tidak memberikan efek negatif pada fisiologis ikan. Ikan mas akan memberikan respon fisiologis yang normal pada keadaan pada kisaran pH 5,5 - 8,5 dan pada temperatur $23^{\circ} \mathrm{C}-30^{\circ} \mathrm{C}$ (Demirkalp, 2007) dan dalam perlakuan ini, $\mathrm{pH}$ dan tempertur air pada bejana masih dalam keadaan yang lebih baik.

Peningkatan ammonium dan terdapatnya partikel abu vulkanik dalam suatu perairan secara bertahap mampu meningkatkan pertumbuhan fitoplankton yang ada dalam bejana perlakuan. Senyawa anorganik yang terlarut dalam air akan diserap oleh fitoplankton untuk aktifitas pertumbuhan. Selain itu fitoplankton juga merupakan makanan ikan (termasuk ikan mas). Pertumbuhan fitoplankton dalam bejana ikan akan menjadi sumber makanan pada ikan selama perlakuan. Nampaknya, hal tersebut terjadi pada perlakuan, terlihat bahwa berat ikan yang diberi perlakuan limbah mengalami peningkatan rata-rata sebesar 2,11 gram, sedangkan pada perlakuan kontrol berat ikan mengalami penurunan rata-rata sebesar 4,23 gram. Penurunan berat ikan merupakan hal yang wajar mengingat selama perlakuan (perlakuan kontrol dan bak kontrol), ikan tidak diberi makan selama 4 hari. Hal ini sengaja dilakukan untuk mencegah penumpukan senyawa organik dan akumulasi racun tubuh yang dihasilkan dari feses dan urin ikan (Hargreaves, 2004). Penumpukan senyawa-senyawa ini mampu menyebabkan keracunan, penurunan kadar oksigen, bahkan kematian pada ikan. Oleh karena itu, dapat diindikasikan bahwa dengan meningkatnya berat badan ikan pada perlakuan limbah menunjukan bahwa terdapat pertumbuhan fitoplankton yang lebih cepat pada bak kontrol. Hal tersebut akan menunjukan bahwa dalam bejana bak kontrol tersebut terdapat materi-materi anorganik yang mampu memicu pertumbuhan fitoplankton dalam bejana.

\section{KESIMPULAN}

Berdasarkan hasil analisis data yang telah dilakukan maka dari penelitian ini dapat disimpulkan bahwa perlakuan ikan mas (Cyprinus carpio) pada perlakuan limbah tidak menyebabkan perubahan yang signifikan pada frekuensi gerakan mulut dan sirip dada (pectoral fin) ikan mas. Namun perlakuan ikan mas pada perlakuan limbah menyebabkan penumpukan partikulat hitam pada insang dan menutupi sebagian lamella insang ikan. Selain itu, tidak ditemukan 
perbedaan struktur jaringan hati ikan yang mas yang diberi perlakuan bak kontrol dan perlakuan kontrol.

Kesimpulan tersebut menunjukan bahwa sejauh ini (terhitung tanggal 20 Juni 2011), kegiatan perawatan Candi Borobudur tidak menyebabkan gangguan pada fisiologi ikan mas (Cyprinus carpio). Hal ini menunjukan bahwa limbah dari perawatan Candi Borobudur tidak memiliki potensi bahaya yang tinggi bagi kesehatan lingkungan atau masih dibawah ambang batas. Masih diperlukan penelitian pendukung untuk mengkuantifikasi potensi bahaya dari limbah perawatan candi tersebut dari beberapa aspek lingkungan yang terkait.

\section{DAFTAR PUSTAKA}

Ayotunde, E.O; Fagbenro, O.A; dan Adebayo, O.T. 2011. Histological Changes in Oreochromis niloticus (Linnaeus I779) Exposed to Aqueous Extract of Moringa oleifera Seeds Powder. Turkish Journal of Fisheries and Aquatic Sciences 11: 37-43

Black, Jacquelyn G. 2005. Microbiology: Principles and Explorations Sixth Edition. John Wiley and Sons, Inc: San Franssisco

Camargo, Marina P. M; Martinez, Cláudia B. R. 2007. Histopathology of Gill, Kidney, and Liver of a Neotrropical Fish Caged in an Urban Stream. Neotropical Ichtyology, 5(3), hal. 327-336

Chahaya, Indra. 2003. Ikan Sebagai Alat Monitor Pencemaran. Disertasi: Fakultas Kesehatan Masyarakat- Universitas Sumatera Utara.

Daffus, J.H 1980. Envinromental Toxicology. Edward Arnold Publisher, Ltd: London

Demirkalp,F Yildiz.2007. Growth Characteristics of Carp (Cyprinus carpio L., 1758) in Liman Lake (Samsun, Turkey). Hacetteoe Journal of Biology and Chemistry, 35(1), hal. 1-8

Drucker, Eliot G; dan Jensen, Jeffrey S. 1996. Pectoral Fin Locomotion in the Striped Surperch (Kinematic Effect of Swimming Speed and Body Size). The Journal of Experimental Biology, 199, hal. 2235-2242

DuPont Land Management. DuPont Herbicides and Water Quality Standards [online]. Didapat dari: www2.dupont.com/Land_Management/en_US L.../K-14744.pdf. [akses: 23 Juni 2011]

Flajšhans, M; dan Hulata, G. 2006. Common carp Cyprinus carpio. Genimpact Final Scienctific Report. Vodnany: University of South Bohemia.

Hargreaves, John A; dan Turker, Craig S.2004. Managing Ammonia in Fish Pound. Southern Regional Aquaculture Centre Publication No. 4603
Gadzała-Kopciuch, R; Berecka; Bartoszewicz, B. J; dan Buszewski,B. 2004. Some Considerations About Bioindicators in Environmental Monitoring. Polish Journal of Environmental Studies, 13(5), hal. 453-462

Indirabai, W. P. S; Tharani, G. Geetha; dan Seetha, P. 2010. Impact of Sublethal Consentration of Endosulfan on Biochemicals and Histology of Organ Tissue of Freshwater Fish, Labeo Robita (Hamilton, 1822). The Bioscan (an International Quarterly Journal of Life Science), 5(2), hal. 215-218

Kikkawa, J; dan Thorne, J. 1974. The Behaviour of Animals. John Murray Publishers ltd: London.

Kramer, Donald L. 1987. Dissolved Oxygen and Fish Behavior. Enviromental Biology of Fishes, 18(2), hal. 81-92

Lewis, William M; dan Morris, Donald. P. 1986. Toxicity of Nitrite o Fish: A Review. Transactions of the American Fisheries Society, 115, hal. 183195

Madigan, Michael T; Martinko, John M; Dunlap, Paul V; dan Clark, David P. 2009. Brock: Biology of Microorganism 12th editon. Pearson Benyamin Cummings: San Francissco

Molles, Manuel C. 2008. Ecolgy Concept \& Applications Fourth Edition. New York : McGraw-Hill.

Palikova, M; dkk. 2004. Histopathology of Carp (Cyprinus carpio L.) Larvae Exposed to Cyanobacteria Extract. ACTA VET-BRNO, 73, hal. 253-257

Parvathi, K; Sivakumar, P; dan Sarasu, C. 2011. Effects of Chromium in Histological Alteration of Gill, Liver, and Kidney of Fresh Water Teleost, Cyprinus carpio (L). Journal of Fisheries International, 6 (1), Hal. 1-5

Pratiwi, Yuli. 2006. Penetuan Tingkat Pencemaran Limbah Industri Tekstil Berdasarkan Nutrition Value Coeficient Bioindikator. Jurnal Teknologi, 3(2), hal 129-137

Raskovic, B; Poleksic, V; Zivic, I; dan Spasic, M.2010. Histology of Carp (Cyprinus Carpio, L.) Gills and Pond Water Quality in Semiintensive Production. Bulgarian Journal of Agricultural Science, 16(3), hal. 253-262

Rusdi; Riyanti; Sifa, Selia; Wahyudi, Dedi P; dan Hamzah, Asep. 2008. Pemanfaatan Tingkah Laku Ikan Mas (Cyprinus carpio) sebagai Bio-Indikator Pencemaran Limbah Domestik. Laporan Program Kreatifitas Mahasiswa - Penulisan Ilmiah .Institut Pertanian Bogor: Depok

Saenphet, Supap; Thaworn, Worawut; dan Saenphet, 
Kanokporn. 2009. Hispathological Alteration of the Gills, Liver, and Kidney in Anabas Testudineus (Bloch) Fish Living in an Unused Lignite Mine, Li District, Lamphun Province, Thailand. South Asian J Trop Med Public Health, 40(3), hal. 1121-1126

Santoso, A. I. 2004. Laporan Analisis Mengenai Dampak Lingkungan Candi Borobudur. Magelang: Balai Studi dan Konservasi Borobudur

Souisa, Devian. 2010. Respon Fisiologi Ikan Mas (Cyprinus carpio) pada Perubahan Salinitas Media [online]. Didapat dari: http://deviansouisa.blogspot.com/-search-?updated-min=2009-0101T00\%3A00\%3A00-08\%3-A00\&updatedmax $=201-0-01-01 \mathrm{~T} 00 \% 3 \mathrm{~A} 00 \% 3 \mathrm{~A} 00-$

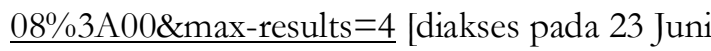
2011]

Swastikawati, Ari. 2007. Laporan Pemagangan Uji Toksisitas. Desertasi. Departemen Kebudayaan dan Pariwisata, Balai Konservasi dan Peninggalan Borobudur.

Wardoyo, STH. 1981. Kriteria Kualitas Air untuk Keperluan Pertanian dan Perikanan. Deserasi PPLHUNDP, Institut Pertanian Bogor. Bogor: 15-38

White, D.; dkk. 2007. New and Evolving Concepts in the Neurotoxicology of Lead. Toxicology and Applied Pharmacology 225 (1): 1-27.

Wilson, Jonathan. M; dan Laurent, Pierre. 2002. Fish Gill Morphology: Inside Out. Journal of Experimental Zoology, 293, hal. 192-213

Wurts, William A. 2004. Pond $p H$ and Ammonia Toxicity. Daily pH Cycle and Ammonia Toxicity, World Aquaculture, 34(2), hal. 20-21

Veil, John A; Rice, James K; dan Raivel, Mary E.S. 1997. Biocide Usage in Cooling Towers in the Electric Power and Petroleum Refining Industries. Laporan. U.S. Department of Energy, Office of Fossil Energy

Velmurugan, Babu; Selvanayagam, Mariadoss; Cengiz, Elif Ipek; Unlu, Erhan. 2009. Histopathological Changes in the Gill and Liver Tissues of Freshwater Fish, Cirrbinus mrigala Exposed to Dicblorvos. Braz. arch. biol. technol.52(5)

Yudhistira, Angga; Antono, Dwi Rian; dan Hendriyanto. 2003. Respon Organisme Akuatik terbadap Variabel Lingkungan $(p H$, Temperatur, Kekeruban, dan Detergen). Disertasi. Departemen Budidaya Perairan, Fakultas Perikanan dan Ilmu Kelautan, Institut Pertanian Bogor

Anonim. Safety Data Sheet Hyamin 1622 [online]. didapat dari: www.fishersci.se/s a- fenet/pdf/0446441.pdf. [akses: 23 Juni 2011]

Anonim². Nitrogen - Ammonia in Water [online]. Didapat dari : http://www.waterresearch.net/Watershed/ammonia.htm. [diakses pada 23 Juni 2011]

Anonim ${ }^{3}$. Focal Necrosis [online]. Didapat dari http://chestofbooks.com/health/-disease/Pathology/Focal-Necrosis.html. [diakses pada 23 Juni 2011]

Anonim ${ }^{4}$. Hepatic Histology: Hepatocytes [online]. Didapat di : http://www.vivo.colostate.edu/hbooks/pathphys/digestion/liver/h isto hcytes.html. [diakses pada 23 Juni 2011]

Anonim ${ }^{5}$. Hyamine ${ }^{\circledR}$ Molecule Structure [online]. Didapat di: http://www.s igmaaldric-h.com/structurei mages $/ 42 / \mathrm{m}$ fcd00011742.gif [diakses pada 23 Juni 2011]

Anonim. Cyprinus carpio Anatomy [online]. Didapat di: http://www.carp-fishing-tactics.com/imagefiles/carpana tomy.jpg [diakses pada 23 Juni 2011

Anonim? ${ }^{7}$. Balai Konservasi Peninggalan Borobudur [online]. $\mathrm{D}$ i d a p a t d i : http://konservasiborobudur.org/v3/201101031 09/statis/BKPBorobudur.html. [diakses pada 4 Juli 2011]

Anonim. Candi Borobudur [online]. Didapat di: http://konservasiborobud ur.org/v3L20110104110/statis/candi-borobudur.html. [diakses pada 4 Juli 2011] 